Progress. Agric. 18(2) : 135-148, 2007

ISSN 1017-8139

\title{
RELATIONSHIP BETWEEN GONAD CONDITION AND NEUROSECRETORY CELL ACTIVITY IN THE GREEN-LIPPED MUSSEL, Perna canaliculus
}

\author{
S. Mahmud ${ }^{1}$, P. V. Mladenov, S. C. Chakraborty ${ }^{2}$ and M. A. R. Faruk ${ }^{3}$ \\ Department of Marine Science, University of Otago, P.O. Box 56, Dunedin, New Zealand
}

\begin{abstract}
The relationship between the activity of neurosecretory cells and gonad development of Perna canaliculus was investigated. The variation in staining intensity of the neurosecretory cells in different ganglia was evaluated. Changes in staining intensity of neurosecretory cells (NSC) were correlated with gonad development. The variation in colour intensity $(\mathrm{CI})$ resulted from differences in the amount of secretory materials within the NSCs. The neurosecretory cell types A and B showed a similar pattern of staining intensity, and showed correlation with gametogenesis and spawning. At the beginning of gonad development, these cells possessed very few granules and the number of granules in the cells increased with gonad maturation. The staining intensity decreased in A and B- cells just after spawning. Cell types $C$ and $D$ did not show any substantial changes in colour intensity with gonad changes.
\end{abstract}

Key Words : Mussel, Gonad development, Neurosecretory cells, Staining intensity

\section{INTRODUCTION}

The morphological features of neurosecretory cells vary considerably in the course of the neurosecretory cycle (Bern and Hagadorn, 1965). The appearance and position of neurosecretory products within the cells vary with the stage of the neurosecretory cycle (Gabe, 1966; Blake, 1972. The concept of neurosecretion is more than just the morphological criteria used to define the cell or the existence of cells in the central nervous system which contain stainable secretory material (Hahn, 1990). The implied significance of neurosecretion is that the product has a physiological function (Bern and Hegadorn, 1965; Hahn, 1990).

Bivalves have presented difficult problems for the study of neurosecretion by classical endocrinological techniques, such as ablation and transplantation (Mathieu et al., 1990). Therefore, most of the information on bivalve neurosecretion comes from seasonal investigations. (Lubet, 1970). Blake (1972) found that the monthly changes in

\footnotetext{
1 Director, Angikar, Bangladesh, 25, West Nakhalpara, Tejgaon, Dhaka-1215, Bangladesh

2 Department of Fisheries Technology, Bangladesh Agricultural University, Mymensingh-2202, Bangladesh

${ }^{3}$ Department of Aquaculture, Bangladesh Agricultural University, Mymensingh-2202, Bangladesh
} 
neurosecretory cells such as size, granulation coincided with the stages of reproductive activity in the bay scallop, Acquipecten irradians. The neurosecretory cells in the clam, Katelysia opima, showed a distinct cycle of activity that correlated with the reproductive cycle (Nagabhushanam and Mane, 1975).

Neurosecretions in bivalves have been associated with reproduction (Illane-Bucher and Lubet, 1980; Mathieu et al., 1994). Seasonal neurosecretory cycles have been correlated with reproductive activity in molluscs (Illanes-Bucher, 1979). These studies have shown that gametogenesis requires the intervention of several neuroendocrine factors during the annual reproductive cycle and support the hypothesis that factors derived from the nervous system play essential roles in the regulation of reproduction (Lubet and Mathieu, 1982).

In gastropods, Hahn (1990) used histological stains to identify the neurosecretory cells and established a cyclical relationship of the stain intensity in certain cells to the reproductive state (gonad maturation and spawning) of the abalone. The changes in quantity and quality of the secretory material of neurosecretory cells should be correlated with seasonal changes or physiological conditions of the animal (Hahn, 1990).

Three types of neural ganglia, cerebral, pedal and visceral, are present in the Greenshell ${ }^{\mathrm{TM}}$ mussel, Perna canaliculus. The cerebral and visceral ganglia contain four types of neurosecretory cells, and the pedal ganglia contain three types of neurosecretory cells based on histological observation (Mahmud and Mladenov, 1998). There is no published data on the hormonal control of gametogenesis in the Greenshell ${ }^{\mathrm{TM}}$ mussel. Therefore, the aim of this study was to investigate the relationship between neurosecretory activity and gonadal development in Perna canaliculus, and to investigate a possible physiological role of neurosecretory cells in the control of reproduction and spawning in this species.

\section{MATERIALS AND METHODS}

\section{Source of mussels}

Greenshell ${ }^{\mathrm{TM}}$ mussels, Perna canaliculus, were collected from an exposed rocky shore at Purihurihu Point, near Blueskin Bay, in the South Island of New Zealand. After transportation, the mussels were quickly transferred to tanks supplied with a constant supply of fresh seawater until the ganglia and gonad were collected. Fourteen to 15 adult mussels of both sexes were sacrificed every month for a total of 18 months (January, 1998 - June, 1999) to collect ganglia and gonad.

\section{Histological preparation of ganglia}

The cerebral, pedal and visceral ganglia were removed from each mussel and preserved in Steive's fixative. Two sets of serial sections $(5 \mu \mathrm{m})$ of each ganglion were made for two different staining methods. The first set was stained with a modified Herlant Pituitary Stain I method (Herlant, 1960) and the second set was stained with a modified Cameron and Steele Aldehyde-Fuchsin method (Ewen, 1962). 


\section{Assessment of staining intensity of the neurosecretory cells}

The neurosecretory cells in all three ganglia were observed and evaluated for their staining affinity using an light microscope. The histological slides were viewed and colour intensity of the neurosecretory cells was visually scored from " 1 " to " 4 ' based on a system slightly modified from Hahn (1990), with "1" representing low, "2" representing medium, " 3 " representing high and " 4 " representing very high staining intensity. Photographs were taken using an Olympus BX50 microscope connected to a digital camera.

\section{Mean colour intensity}

Several cells (10-15) of each cell type in individual ganglia were viewed and assigned a score according to their colour intensity. This was done for each mussel in the sample and a mean colour intensity (CI) was calculated for the sample. CI was calculated for each cell type in each ganglia. This was expressed as:

Mean colour intensity $(\mathrm{CI})=\sum^{\mathrm{n}} \mathrm{Ci} / \mathrm{N}$

Where, $\mathrm{Ci}=$ assigned colour intensity of neurosecretory cells in individual mussel, $\mathrm{N}=$ total number of mussels in sample; $n=$ No. of neurosecretory cells present in each sample.

\section{Statistical analysis}

Mean colour intensity (CI) for each neurosecretory cell type in different ganglia at each gonad stage was calculated and compared using ANOVA. The non-parametric Mann Whitney U-test was performed to identify significant differences between the means of colour intensity of successive gonad stages. Values are significant by Bonferroni's coefficient where $\mathrm{p}<0.0045$.

\section{Histological preparation of gonads}

A small section of the gonad $(5 \mathrm{~mm} \times 8 \mathrm{~mm}$ ) from the middle portion of the extended mantle gonad tissue was excised from each individual mussel using a scalpel and immediately preserved in Bouin's fixative (Humason, 1979). The tissues were then dehydrated through a graded series of ethanol, infiltrated with molten wax and cleared with xylene using an automatic tissue processor, and embedded in paraffin (melting point 56 to $58^{\circ} \mathrm{C}$ ). The gonads were sectioned at $7 \mu \mathrm{m}$. The gonad sections were then stained with haematoxylin and eosin (Hahn, 1990).

\section{Staging of gonads}

Sectioned gonads from both sexes were viewed and evaluated using an Olympus Vanox light microscope. The gonad state was classified using a modification of Seed's (1969) method. Gonad development was divided into five main gametogenic stages: developing, ripe, spawning, spent and resting. The developing and spawning stages were subdivided into four sub-classes. Thus, 11 gonad stages were recorded. Photographs were taken using an Olympus BX50 microscope connected to a digital camera. 


\section{RESULTS}

\section{Gonad Staging}

The reproductive stage of Perna canaliculus was determined from histological sections of the gonads and were classified on the basis of the morphology of the germinal follicle and the maturity of the gametes present. The eleven gonad stages in females and males are shown in Figs. 1-2.

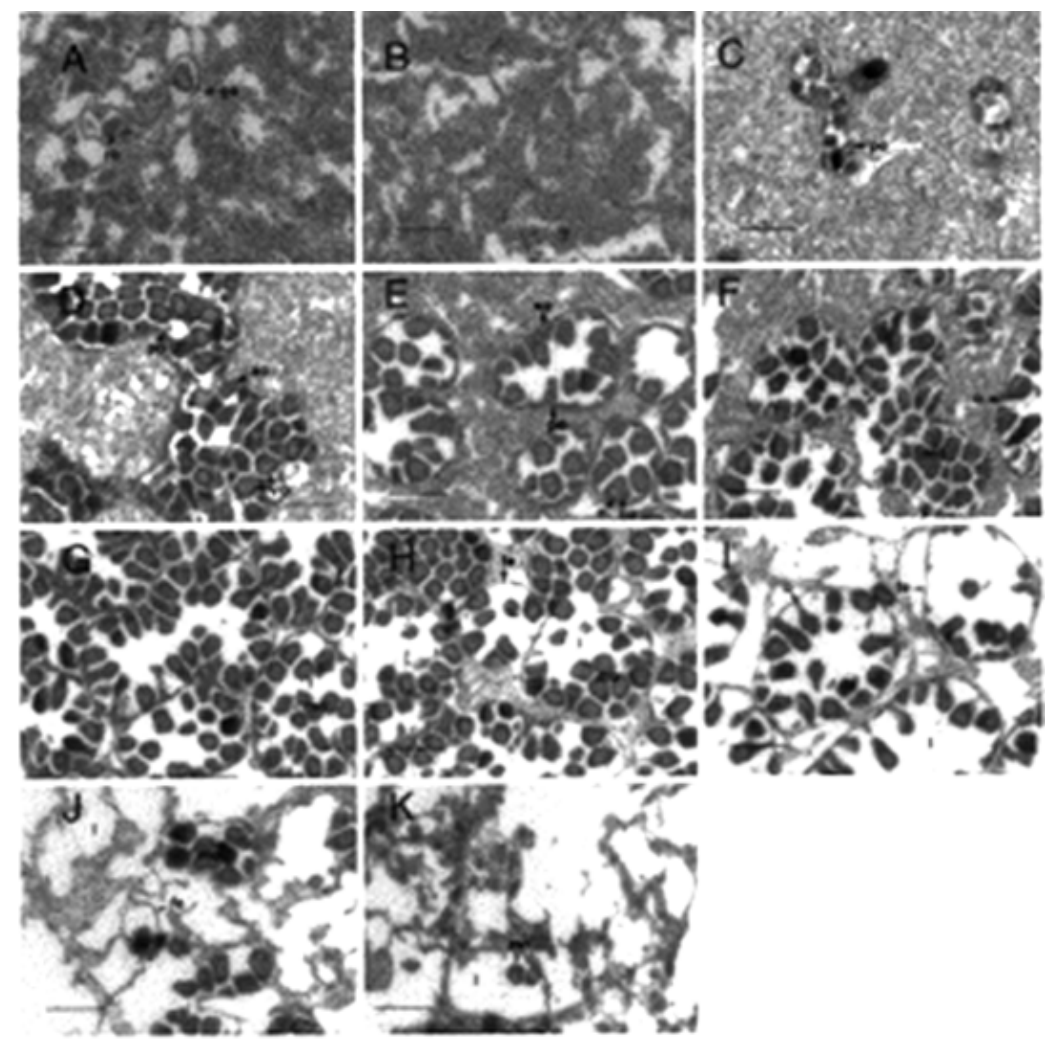

Fig. 1. Histological sections of the gonad of Perna canaliculus showing eleven stages in female gonad development. All sections were stained with haematoxylin and eosin. Scale bar $20 \mu \mathrm{m}$.

(A) Stage 1 : Spent, (B) Stage 2 : resting. No follicles present, (C) Stage 3 : Developing-A, (D) Stage 4: Developing-B, (E) Stage 5 : Developing-C, (F) Stage 6 : Developing-D, (G) Stage 7 : Ripe, (H) Stage 8 : Spawning-A, (I) Stage 9 : Spawning-B, (J) Stage 10 : Spawning-C, (K) Stage 11 : Spawning-D. fe, follicle epithelium; ge, germinal epithelium; l, lumen; mo, mature oocyte; n, nucleus; nu, nucleolus; o, stalked oocyte; po, primary oocyte; ro, relict oocyte; so, secondary oocyte; vo, vitellogenic oocyte.

\section{Neurosecretory cell activity}

The colour intensity and the inclusion materials in the neurosecretory cells varied with gonad stage. Differences in colour intensity and neurosecretory granules were observed 
mostly in cell types A and B. Different categories of colour intensity in the neurosecretory cells in the ganglia of Perna canaliculus are described and presented in Table 1 and Figs. 3-4.

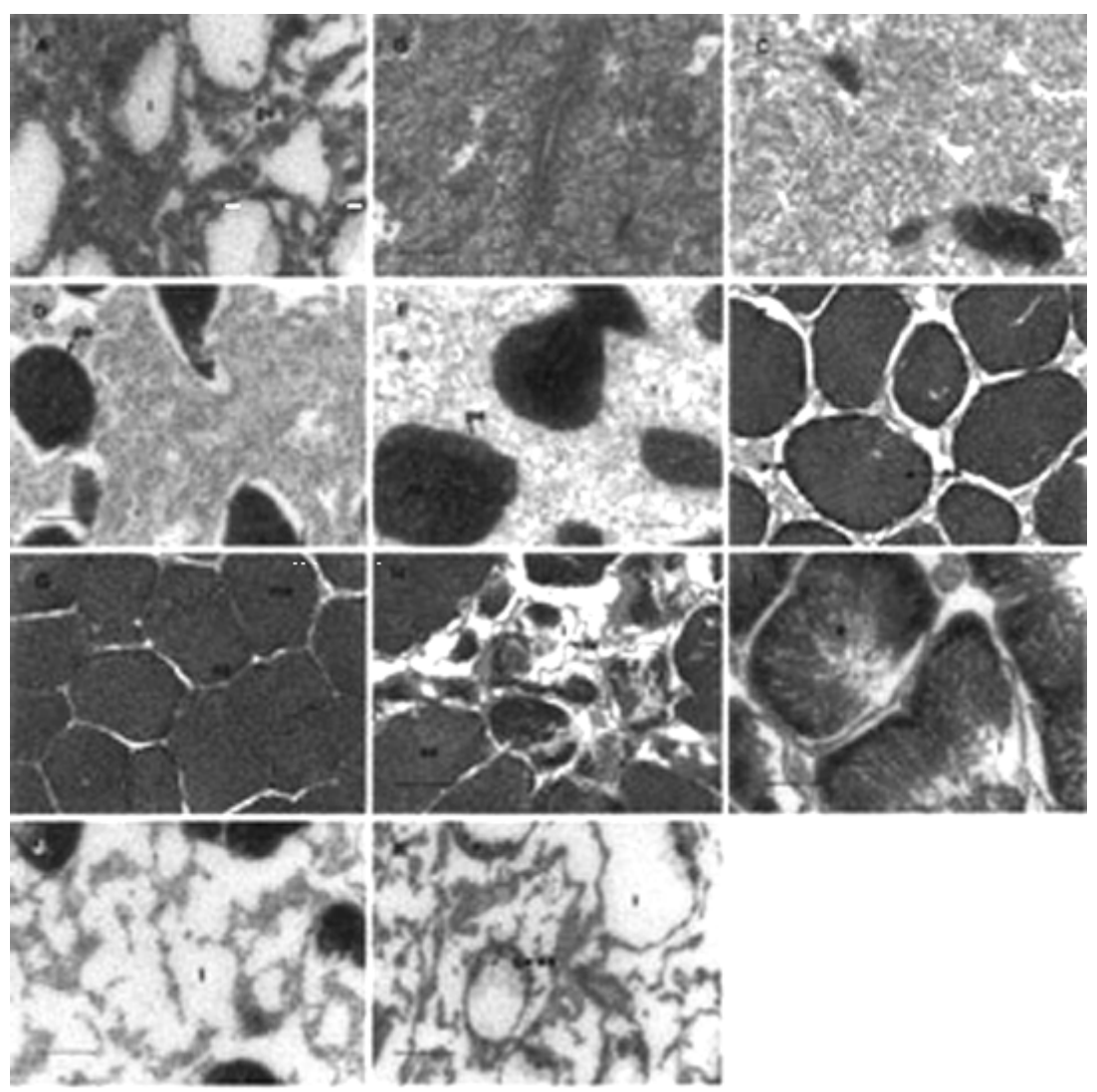

Fig. 2. Histological sections of the gonad of Perna canaliculus showing eleven stages in male gonad development. All sections were stained with haematoxylin and eosin. Scale bar $20 \mu \mathrm{m}$

(A) Stage 1 : Spent, (B) Stage 2 : resting. No follicles present, (C) Stage 3 : Developing-A, (D) Stage 4 : Developing-B, (E) Stage 5 : Developing-C, (F) Stage 6 : Developing-D, (G) Stage 7 : Ripe, (H) Stage 8 : Spawning-A, (I) Stage 9 : Spawning-B, (J) Stage 10 : Spawning-C, (K) Stage 11 : Spawning-D. fe, follicle epithelium; ge, germinal epithelium; 1, lumen; ms, mature spermatozoa, ps, primary spermatocytes; sp, secondary spermatocytes; s, spermatid.

\section{Relationship between gonad condition and neurosecretory cell activity}

The changes in colour intensity of neurosecretory cells were found to correlate with gonad condition in cell types A and B (Figs. 5-7). These cells showed low staining intensity at the beginning of gonad development and then began to accumulate staining materials when mussels started to gain maturity. The colour intensity in A and B cells 
was significantly different between many gonad stages of gonads $(p<0.0045$; Table 2$)$. The staining intensity of these cells decreased significantly with the spawning of the gonads $(p<0.0045)$. In cerebral ganglia, cell types $C$ and $D$ did not show any substantial changes in colour intensity ( $p>0.0045)$ with changes in gonad stage except a small increase in colour intensity in C-cells during the 'ripe' stage of gonad development (Fig. 5).

As in cerebral ganglia, the staining intensity of neurosecretory cells in the pedal ganglia was found to be correlated with the progress of gonad maturation (Fig. 6). The staining intensity in A-cells increased sharply with gonad development and showed a significant difference between stages 3 and 4 , and 4 and 5 ( $p<0.0045$; Table 3 ). The staining intensity of this cell decreased sharply after spawning and at the end of spawning stages $(\mathrm{p}<0.0045)$. C and D-cells showed little change in staining intensity with changes in gonad state $(\mathrm{p}>0.0045)$, and the correlation was weak (Fig. 6).

Table 1. Categories in colour intensity in the neurosecretory cells in the ganglia of Greenshell $^{\mathrm{TM}}$ mussel, Perna canaliculus

\begin{tabular}{|c|c|c|}
\hline Colour intensity & Score & Description \\
\hline Low & 1 & $\begin{array}{l}\text { This stage of neurosecretion is characterised by the presence of a } \\
\text { small number of secretory granules that appear diffusely in the } \\
\text { cytoplasm of the cell. The neurosecretory cells in this group reveal } \\
\text { low cytoplasmic staining intensity (Figs. } 3,4 \mathrm{~A} \text { ). }\end{array}$ \\
\hline Medium & 2 & $\begin{array}{l}\text { The numbers of granules increase in the cytoplasm. The cytoplasm of } \\
\text { cells contains a small area sharply demarcated from the rest by the } \\
\text { accumulation of granules. The colour intensity of the neurosecretory } \\
\text { cells is slightly higher than in the previous stage (Figs. } 3,4 \mathrm{~B} \text { ). }\end{array}$ \\
\hline High & 3 & $\begin{array}{l}\text { The neurosecretory granules are more abundant in the cytoplasm of A } \\
\text { and B-cells in different ganglia, and staining intensity is higher than } \\
\text { in the previous stage (Figs. } 3,4 \mathrm{C} \text { ). Few vacuoles are observed in the } \\
\text { neurosecretory cells of mussels that have reached spawning stage. }\end{array}$ \\
\hline Very high & 4 & $\begin{array}{l}\text { Secretory material fills the cytoplasm as a uniform mass due to the } \\
\text { close packing of the granules. The neurosecretory cell types A and B } \\
\text { in different ganglia reach their point of maximal colour intensity } \\
\text { (Figs. 3, 4D). }\end{array}$ \\
\hline
\end{tabular}

Table 2. $\mathrm{P}$ values from Mann Whitney U-test for colour intensity of four types of neurosecretory cells in the cerebral ganglia of Perna canaliculus between successive gonad stages

\begin{tabular}{l|c|c|c|c|c|c|c|c|c|c}
\hline & $1-2$ & $2-3$ & $3-4$ & $4-5$ & $5-6$ & $6-7$ & $7-8$ & $8-9$ & $9-10$ & $10-11$ \\
\hline $\mathrm{A}_{\mathrm{c}}$ & 1.000 & 0.000 & 0.000 & 0.000 & 0.277 & 0.125 & 0.000 & 0.070 & 0.001 & 0.001 \\
$\mathrm{~B}_{\mathrm{c}}$ & 0.598 & 0.001 & 0.003 & 0.000 & 0.729 & 1.000 & 0.002 & 0.157 & 0.045 & 0.003 \\
$\mathrm{C}_{\mathrm{c}}$ & 1.000 & 1.000 & 1.000 & 0.661 & 0.650 & 0.381 & 0.037 & 1.000 & 1.000 & 1.000 \\
$\mathrm{D}_{\mathrm{c}}$ & 1.000 & 1.000 & 0.448 & 0.219 & 0.597 & 1.000 & 0.344 & 1.000 & 1.000 & 1.000 \\
\hline
\end{tabular}




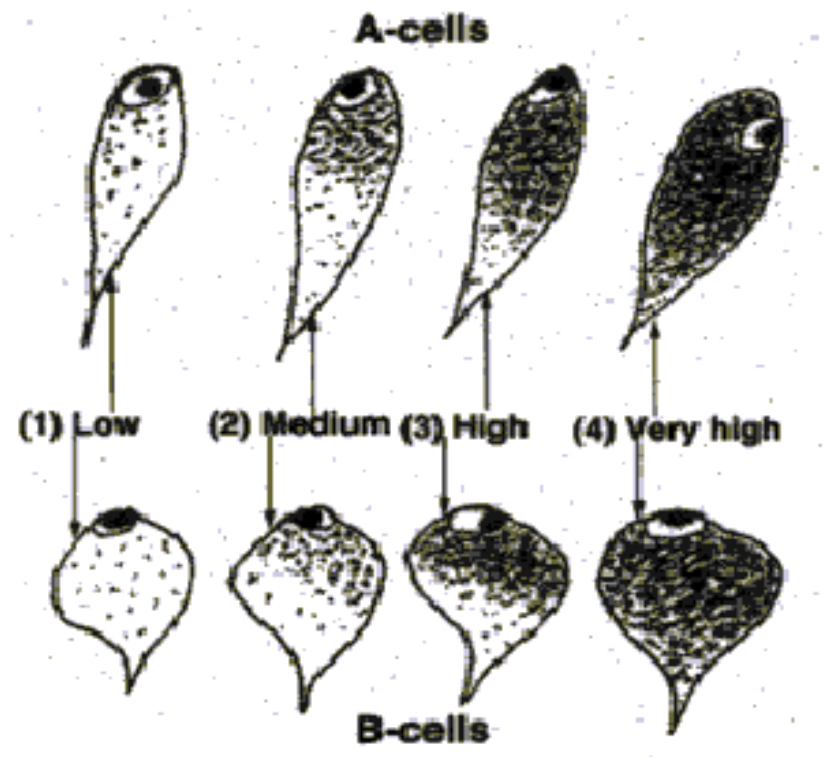

Fig. 3. Schematic diagram of neurosecretory cell types A and B of Perna canaliculus showing different categories of colour intensity (not drawn to scale)
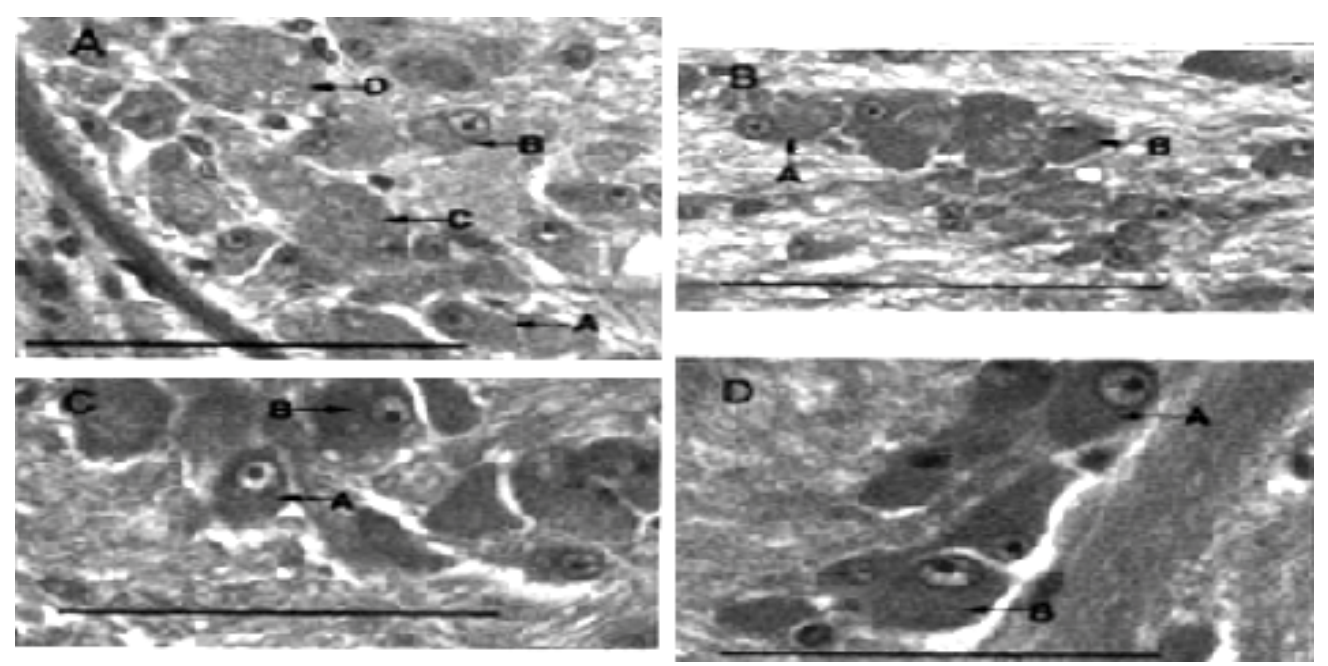

Fig. 4. Histological sections of the ganglia of the Greenshell ${ }^{\mathrm{TM}}$ mussel, Perna canaliculus, showing different categories of colour intensity in the neurosecretory cells. All sections were stained with Herlant's. Scale bar $50 \mu \mathrm{m}$.

(A) Low colour intensity (Stage 1) in cell types A, B, C and D of the cerebral ganglia.

(B) Medium colour intensity (Stage 2) in cell types A and B of the cerebral ganglia.

(C) High colour intensity (Stage 3) in cell types A and B of the visceral ganglia.

(D) Very high colour intensity (Stage 4) in cell types A and B of the cerebral ganglia. 

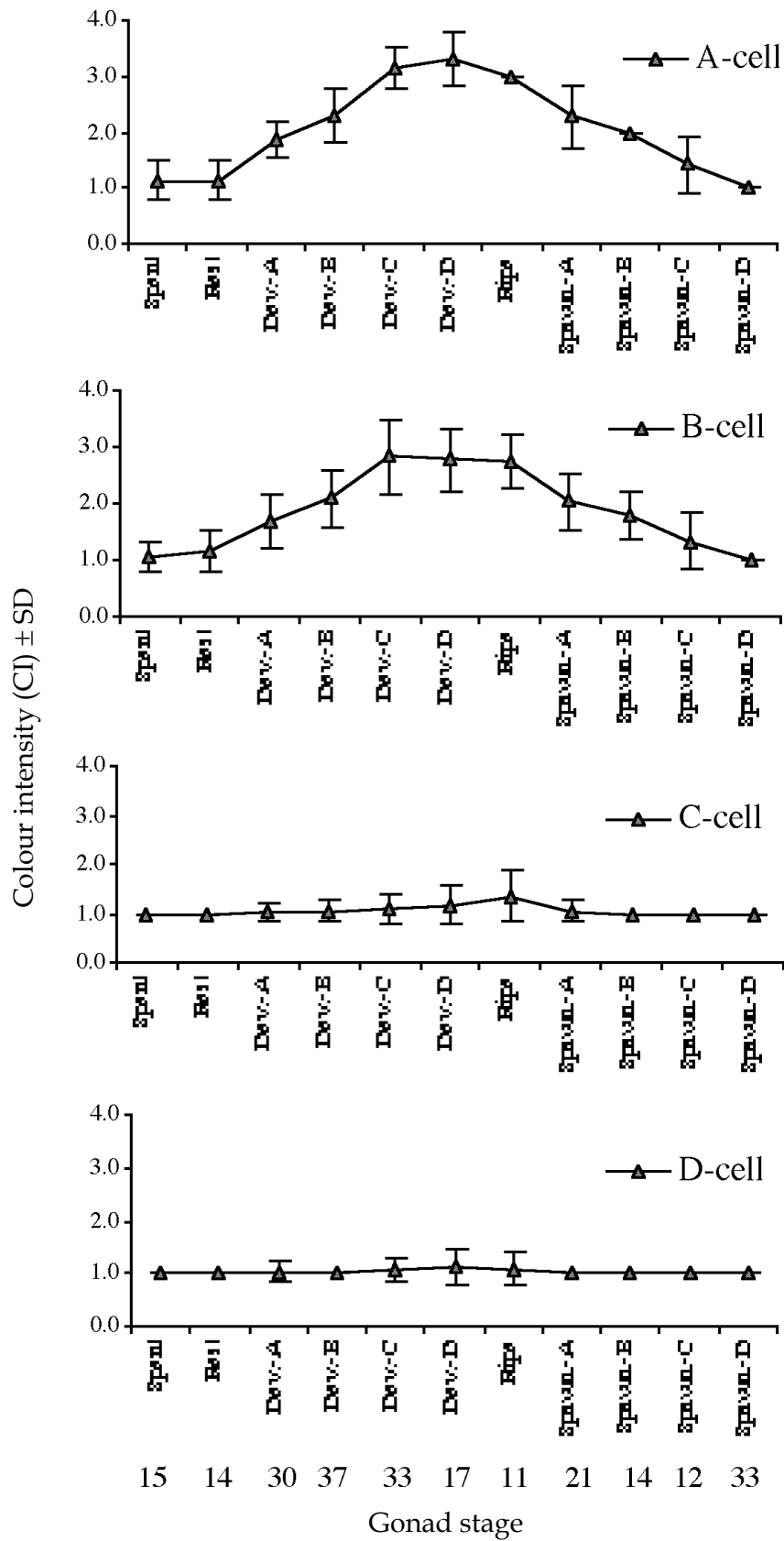

Fig. 5. Activity of different neurosecretory cells in the cerebral ganglia in relation to gonad stages in Greenshell ${ }^{\mathrm{TM}}$ mussel, Perna canaliculus. Numbers at the bottom represent the sample size at each gonad stage. The error bars represent the standard deviation of mean colour intensity 

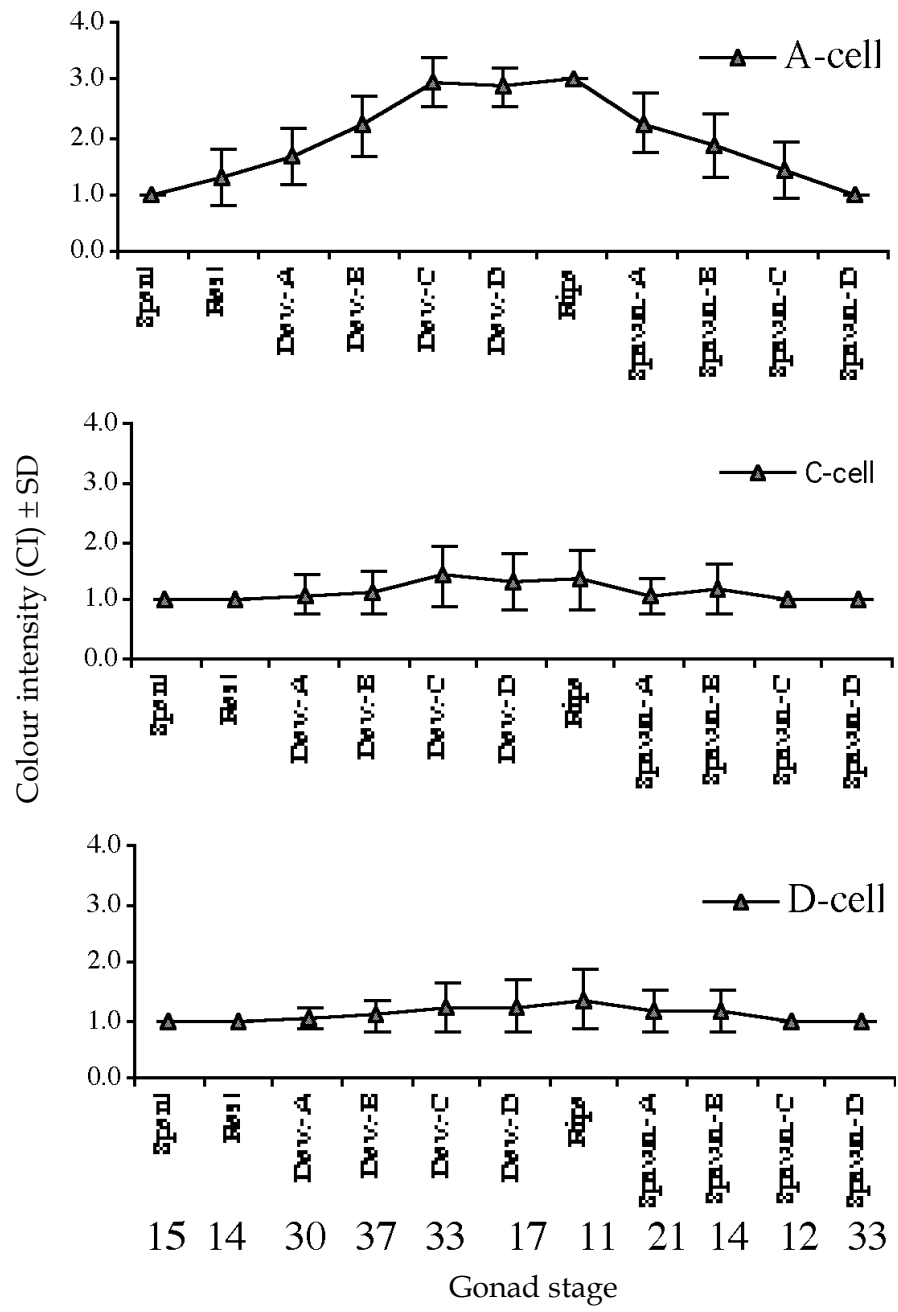

Fig. 6. Activity of different neurosecretory cells in the pedal ganglia in relation to gonad stages in Greenshell ${ }^{\mathrm{TM}}$ mussel, Perna canaliculus. Numbers at the bottom represent the sample size at each gonad stage. The error bars represent the standard deviation of mean colour intensity.

Table 3. P values from Mann Whitney U-test for colour intensity of three types of neurosecretory cells in the pedal ganglia of Perna canaliculus between successive gonad stages

\begin{tabular}{l|c|c|c|c|c|c|c|c|c|c}
\hline & $1-2$ & $2-3$ & $3-4$ & $4-5$ & $5-6$ & $6-7$ & $7-8$ & $8-9$ & $9-10$ & $10-11$ \\
\hline $\mathrm{A}_{\mathrm{p}}$ & 0.042 & 0.025 & 0.000 & 0.000 & 0.715 & 0.505 & 0.000 & 0.058 & 0.074 & 0.003 \\
$\mathrm{C}_{\mathrm{p}}$ & 1.000 & 0.540 & 0.722 & 0.008 & 0.540 & 1.000 & 0.148 & 0.627 & 0.225 & 1.000 \\
$\mathrm{D}_{\mathrm{p}}$ & 1.000 & 1.000 & 0.620 & 0.177 & 1.000 & 0.671 & 0.197 & 1.000 & 0.480 & 1.000 \\
\hline
\end{tabular}



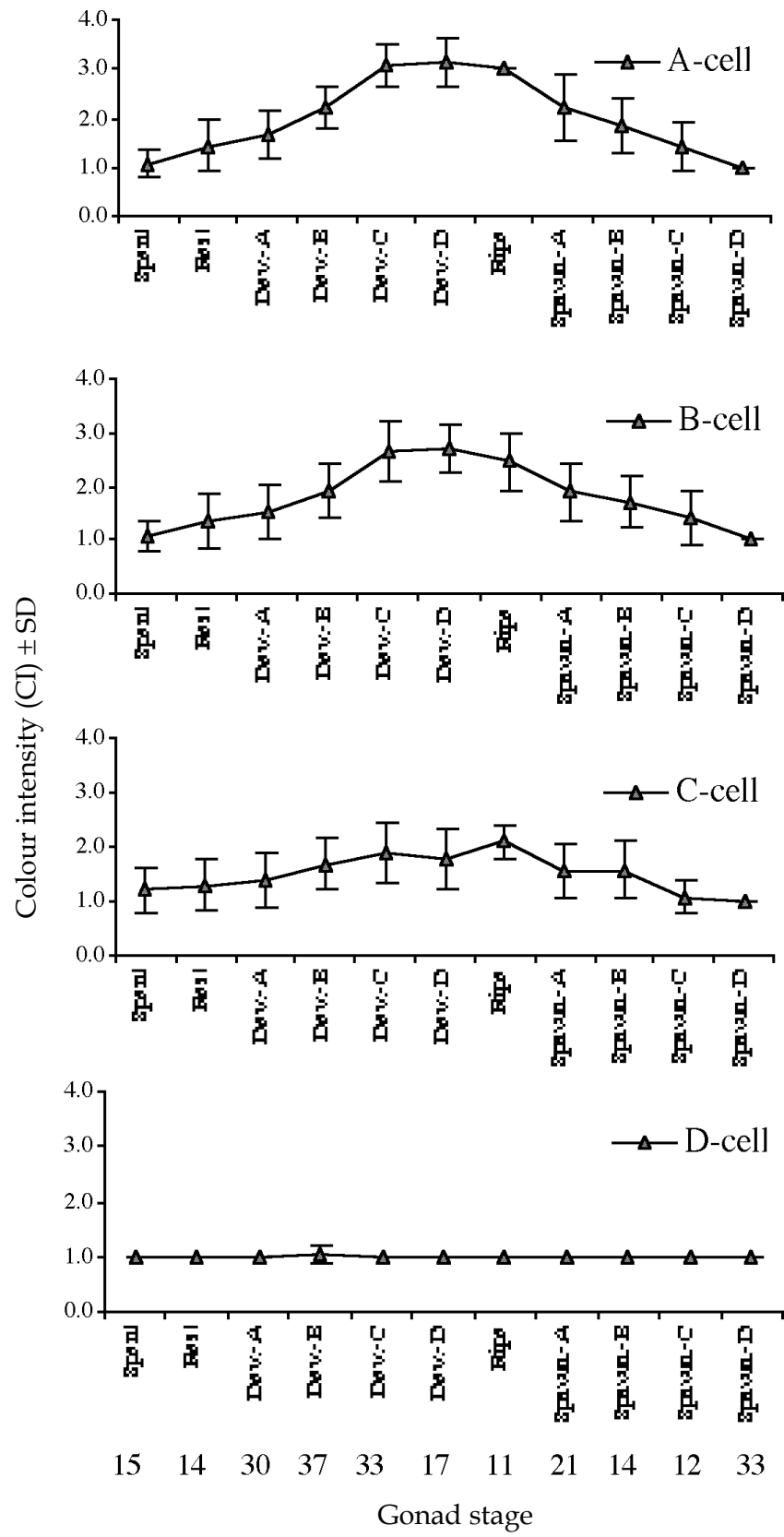

Fig. 7. Activity of different neurosecretory cells in the visceral ganglia in relation to gonad stages the Greenshell ${ }^{\mathrm{TM}}$ mussel, Perna canaliculus. Numbers at the bottom represent the sample size at each gonad stage. The error bars represent the standard deviation of mean colour intensity 
Table 4. P values from Mann Whitney U-test for colour intensity of four types of neurosecretory cells in the visceral ganglia of Perna canaliculus between successive gonad stages

\begin{tabular}{l|c|c|c|c|c|c|c|c|c|c}
\hline & $1-2$ & $2-3$ & $3-4$ & $4-5$ & $5-6$ & $6-7$ & $7-8$ & $8-9$ & $9-10$ & $10-11$ \\
\hline $\mathrm{A}_{\mathrm{v}}$ & 0.035 & 0.327 & 0.000 & 0.000 & 0.658 & 0.441 & 0.000 & 0.133 & 0.074 & 0.001 \\
$\mathrm{~B}_{\mathrm{v}}$ & 0.080 & 0.342 & 0.004 & 0.000 & 0.692 & 0.248 & 0.019 & 0.347 & 0.233 & 0.001 \\
$\mathrm{C}_{\mathrm{v}}$ & 0.682 & 0.521 & 0.029 & 0.141 & 0.543 & 0.078 & 0.007 & 1.000 & 0.014 & 0.267 \\
\hline $\mathrm{D}_{\mathrm{v}}$ & 1.000 & 1.000 & 1.000 & 1.000 & 1.000 & 1.000 & 1.000 & 1.000 & 1.000 & 1.000 \\
\hline
\end{tabular}

In visceral ganglia, the A-cells and B-cells showed significant changes in staining intensity than the C and D-cells. The fluctuation of colour intensity in cell types A and B was related to gonad condition and showed significant variations in colour intensity between developing stages $(\mathrm{p}<0.0045$; Table 4$)$. After a slight decrease with the ripe stage, the colour intensity of these cells dropped sharply $((p<0.0045)$ with the spawning condition of the gonads (Fig. 7). Cell type $C$ showed a small increase in colour intensity and cell type D showed the same colour intensity throughout the gonadal development (Fig. 7).

Cell types A and B in all different ganglia (Figs. 5-7) showed a similar pattern of staining intensity with the changes of gonad development. The maximum colour intensity was between the stages of Developing-C and Developing-D and showed a significant difference in colour intensity $(p<0.0045$; Table 2-4). Again, the colour intensity of cell types A and B in different ganglia showed a sharp decrease with spawning $(\mathrm{p}<0.0045$; Tables 2-4). C-cells of the pedal and visceral ganglia showed a little affinity for stain during gonad ripening (Figs. 6-7). Cell type D in all three ganglia showed constant staining throughout all gonad conditions (Figs. 5-7).

\section{DISCUSSION}

This study used the modified classification of Seed (1969) to categorise the gonad state of mussels. By measuring the level of gonad maturation in each mussel, the staining intensity in different neurosecretory cells could be correlated to the level of gonad maturation. This method was employed for bivalves by Umiji (1969) in Mytilus perna, Blake (1972) in Aequipecten irradian, and for gastropods by Duce (1975) in A. raculatus, and by Hahn (1990) in Haliotis discus hannai.

Variation of colour intensity was observed in cell type 'A' in all three ganglia. Cell type 'B' showed similar variation of colour intensity in cerebral and the visceral ganglia. A slight variation (not significant) of colour intensity in cell types $C$ and D was observed within cerebral, pedal and the visceral ganglia. The cell types A and B in all three ganglia possessed a greater abundance of neurosecretory granules than cell types ' $C$ ' and 'D'. Gabe (1966) observed that in some cells neurosecretory granules are sparse, while in others they are abundant. 
Cell types ' $\mathrm{A}$ ' and ' $\mathrm{B}$ ' in the different ganglia of the Greenshell ${ }^{\mathrm{TM}}$ mussel, Perna canaliculus, were morphologically very similar except for small differences in shape (Mahmud and Mladenov, 1998). Cell types ' $\mathrm{C}$ ' and ' $\mathrm{D}$ ' in the ganglia were also very similar in morphology. These authors also observed that the morphological characteristics of A-cells in the cerebral, pedal and visceral ganglia were very similar, with only small differences in size. This was also the case for ' $\mathrm{B}$ ', ' $\mathrm{C}$ ' and ' $\mathrm{D}$ '-cells of cerebral, pedal and visceral ganglia. In this study, all four types of neurosecretory cells showed consistency with their observations in morphological features, in addition to the similar pattern in staining intensity of these cells. Thus, these results indicate a possibility of similar physiological functions for these cells.

The staining intensity of cell types A and B in all three ganglia showed a correlation to gametogenesis in the gonad. The neurosecretory granules in these cells continued to increase while the oocyte volume was increasing dramatically during the period of oogenesis/spermatogenesis. The secretions in cell types A and B probably controlled oogenesis/vitellogenesis in Perna canaliculus, since the cycle of neurosecretory material closely followed that of gonadal development.In molluscs, staining properties of neurosecretory cells have been correlated with the time of year and reproductive activity. The accumulation of neurosecretion in the pear-shaped cells of the cerebral ganglia of Mytilus edulis and Mytilus galloprovincialis occurs during the phase of gametogenesis (Lubet, 1959). Thus, the results found in other molluscan species are similar to the observations in the present study for the Greenshell ${ }^{\mathrm{TM}}$ mussel, Perna canaliculus. This suggests that cell types A and B contain certain neurohormone(s) which control reproduction in this species, and these factors need to be characterised in future studies.

In the present study, cell types A and B in all ganglia of the Greenshell ${ }^{\mathrm{TM}}$ mussel, Perna canaliculus (Figs. 3-5) also showed a strong correlation to spawning. As soon as the mussels spawned, A and B-cells decreased in staining intensity. The difference in staining before and after was very evident. These results suggest that the neurosecretory cell types A and B in different ganglia of the Greenshell ${ }^{\mathrm{TM}}$ mussel contain a factor that could induce spawning, either directly or indirectly. The production of spawning factor(s) or homologous hormone(s) in the ganglia appears to be a general feature in molluscs (Croll et al., 1993). It is theorised that the hormones and the cells synthesising them in these animals may be homologous (Ram, 1977). It will therefore not be surprising to find homologous hormone(s) in the ganglia of Greenshell ${ }^{\mathrm{TM}}$ mussels. However, this study is only suggestive of the presence of active hormones in cell types $\mathrm{C}$ and $\mathrm{D}$, and it would be very informative to determine the nature of these hormone(s) in this bivalve species.

Involvement of neurosecretory cells in spawning was evident for cell type 7 in visceral ganglia of abalone studied by Yahata (1973). When mature female Haliotis discus hannai were injected with homogenates of the ganglia there was significant swelling and softening of the ovary, which was combined with an increase in body weight. Also, these animals spawned a large number of fertilisable eggs the day following the injection (Yahata, 1973). Injecting ganglionic homogenates of Greenshell ${ }^{\mathrm{TM}}$ mussel would be one 
approach to evaluating the factors contained in ganglia in induction of spawning in this species.

The staining intensity of $\mathrm{C}$ and $\mathrm{D}$ cells did not show any correlation to either gametogenesis, vitellogenesis or spawning. These cells probably controlled some physiological functions that were not measured in this study.

In the present study, the examination of neurosecretory cells by light microscopy revealed differences in their staining intensity from one stage to another stage of gonad development in the Greenshell ${ }^{\mathrm{TM}}$ mussel. However, any attempts to correlate changes in histology with physiological fluctuations have a number of inherent problems that need special attention in such a study. Firstly, differences in histological appearance or staining intensity can be due to histological staining procedure. In this study uniform, preparative techniques as well as stains from the same batch were applied in an attempt to minimise this problem. Secondly, the gonad development has been correlated with the changes in the colour intensity of the neurosecretory cells in different ganglia. However it is possible that other physiological changes such as temperature, light which may be influencing the neurosecretory cells could also be involved. Therefore it is not safe to conclude that only neurosecretory substances directly regulate gonad activity, and a study under controlled conditions possibly could minimise these factors.

\section{REFERENCES}

Bern, H. A. and Hagadorn, I. R. 1965. Mollusca : Pelecypoda and Scaphopoda. In, Structure and Function in the Nervous System of Invertebrates, Vol. II. (Eds., T. H. Bullock and G. A. Horridge), W. H. Freeman, San Francisco. pp. 1388-1431.

Blake, N. J. 1972. Environmental regulation of neurosecretion and reproductive activity in the bay scallop, Acquipecten irradians (Lamarck). Ph. D. Dessertation, University of Rhode Island, Kingston.

Croll, R. P., Nason, J. and Minnen, J. V. 1993. Characterization of central neurons in bivalves using antibodies raised against neuropeptides involved in gastropod egg-laying behaviour. Invert. Reprod. Develop., 24(3) : 161-168.

Duce, I. 1975. Studies on possible endocrine structures of the central nervous system of Agriolimax reticulatus. Ph.D. Thesis, Univ. Coll. of North Wales, Bangor, Wales, UK.

Ewen, A. B. 1962. An improved aldehyde-fuchsin staining technique for neurosecretory products in insects. Trans. Ami. Micros. Soc., 81 : 94-96.

Gabe, M. 1966. Neurosecretion, Oxford, Pergamon Press. pp. 124

Hahn, K. O. 1990. Neurosecretory staining in the cerebral and pleural-pedal ganglia of Haliotis discus hannai and Trochus niloticus, and its relationship to reproduction. Ph. D. Thesis, University of California, Davis.

Herlant, M. 1960. Étude critique de deux techniques nouvelles destinées a mettre en évidence les différentes catégories cellularies dans la glande pituitaire. Bulletin de microscopie Appliquée, $10: 37-44$.

Humason, G. L. 1979. Animal Tissue Techniques. $2^{\text {nd }}$ edn. San Francisco, W. H. Freeman and Co. 
Illanes-Bucher, J. 1979. Recherches cytologiques et expérimentales sur la neurosécrétion de la moule, Mytilus edulis L. Thèse Doct. Sp. Caen., pp. 1-134.

Illanes-Bucher, J. and Lubet, P. 1980. Etude de activité neurosécrétrice au cours du cycle sexuel annuel de la moule (Mytilus edulis L.). Mollusque Lamellibranche. Bull. Soc. Zool. Fr., 105(1) : 141-145.

Lubet, P. 1959. Recherches sur le cycle sexual et I'emission des gamètes chez les Mytilidés et les Pectinidés. Rev. Trav. Inst. Peches Marit., 23(3) : 387-548.

Lubet. P. 1970. Experimental data on the effects of removal of nerve ganglia of pelecypod mollusks. In, Invertebrate Organ Cultures. (Ed., H. Lutz), Gordon and Breach, New York. pp. 153-165.

Lubet, P. and Mathieu, M. 1982. The action of internal factors on gametogenesis in pelecypod molluscs. Malacologia, 22(1-2) : 131- 136.

Mahmud, S. and Mladenov, P. V. 1998. Characterisation of neurosecretory cells in the greenshelled mussel, Perna canaliculus. Abstract: Joint conference, New Zealand Marine Sciences Society, Australian Society for Phycology and Aquatic Botany, Dunedin, New Zealand. pp. 138.

Mathieu, M., Robbins, I. and Lenoir, F. 1990. A novel approach to the neuroendocrine control of gametogenesis and the gametogenesis-related storage cycle of Mytilus edulis L. In, Advances in Invertebrate Reproduction. Vol. 5 (Eds., M. Hoshi and O. Yamashita), Elsvier Science Publishers (biomedical Division). pp. 239-245.

Nagabhushanam, R., and Mane, U. H. 1973. Neurosecretory in the clam, Ketelysia opima. Marthwada J. Sci., $12: 193-203$.

Ram, J. L. 1977. Hormonal control of reproduction in Busycon : Laying of egg capsules caused by nervous sytem extracts. Biol., Bull., 152 : 221-232.

Seed, R. 1969. The ecology of Mytilus edulis L. (Lamellibranchia) exposed rocky shores. 1. Breeding and settlement. Oecologia, 3 : 277-316.

Umiji, S. 1969. Neurosecretion in the mussel Mytilus perna Bol. Fac. Filos. Cienc. Let., Univ. Sao Paulo, $26: 181-254$.

Yahata, T. 1973. Induced spawning of abalone (Nordotis discus Reeve) injected with ganglionic suspensions. Bull. Jap. Soc. Sci. Fish., 39(11) : 1117-1122. 